\title{
IMPLEMENTASI PENANGANAN KASUS KEKERASAN TERHADAP ANAK OLEH KOMISI PERLINDUNGAN ANAK INDONESIA
}

\author{
Implementation of Cases of Violence Against Children by the \\ Commission for the Protection by Children Indonesia
}

\author{
Dwi Putri Melati \\ Fakultas Hukum Universitas Sang Bumi Ruwa Jurai \\ email: dwiputri.melati@yahoo.com
}

\begin{abstract}
The Government held protection of children with a Child Protection Commission based on the mandate Presidential Decree Number 77 of 2003 on Child Protection Commission and Law Number 23 of 2002 on Child Protection. The problem of Indonesian Child Protection Commission (KPAI) implementation in handling cases of violence against children and Protection Commission apasaja resistance factors Indonesian Children to the protection cases of violence against children. Writing nomative juridical approach and use nomative juridical approach empirical. Discussions on Normative KPAI socialization gather data and information, received complaints review, do, monitoring, and evaluation, report, advice inputs, and consideration to the President. KPAI will ideally plays a monitor, monitor and encouragement organizer child protection, policy advocacy, as the mediator in the handling cases of violence against children. Some of the factors that would be resistance KPAI in dealing with cases of violence against children in terms of the method seen from law enforcement officials, the law,the lack public understanding on children's rights, facilities as the minimum support infrastructure, there is a tradition negative community authors suggest that Indonesian Child Protection Commission raises really carry out an effective and professional, the Government gives infrastructure, facilities, facilities and infrastructure that enough, people can understand children's rights and understand.
\end{abstract}

Keywords : Implementation, Handling, Children.

\section{abstrak}

Pemerintah menyelenggarakan perlindungan anak dengan membuat Komisi Perlindungan Anak berdasarkan amanat Keppres Nomor 77 Tahun 2003 tentang Komisi Perlindungan Anak dan Undang-Undang Nomor 23 Tahun 2002 tentang Perlindungan Anak. Permasalahannya mengenai implementasi 
Komisi Perlindungan Anak Indonesia (KPAI) dalam penanganan kasus kekerasan terhadap anak dan apa saja faktor penghambat Komisi Perlindungan Anak Indonesia terhadap perlindungan kasus kekerasan terhadap anak. Penulisan ini menggunakan pendekatan yuridis normatif dan pendekatan yuridis empiris. Pembahasan secara Normatif KPAI bertugas melakukan sosialisasi mengumpulkan data dan informasi, menerima pengaduan masyarakat, melakukan penelaahan, pemantauan dan evaluasi, memberikan laporan, saran, masukan, dan pertimbangan kepada Presiden. KPAI secara idealnya berperan memantau, mengawasi dan memberi dorongan penyelenggara perlindungan anak, melakukan advokasi kebijakan, sebagai mediator dalam penanganan kasus kekerasan terhadap anak. Beberapa faktor yang menjadi penghambat KPAI dalam menangani kasus kekerasan terhadap anak dilihat dari segi kaidah hukum, aspek aparat penegak hukum, minimnya pemahaman masyarakat mengenai hak anak, fasilitas berupa minimnya dukungan infrastruktur, ada tradisi negatif masyarakat penulis menyarankan agar Komisi Perlindungan Anak Indonesia melaksanakan kinerjanya benar-benar secara efektif dan profesional, pemerintah memberikan infrastruktur, fasilitas, sarana dan prasarana yang memadai, masyarakat dapat mengerti dan memahami hak anak.

Kata Kunci: Implementasi, Penanganan, Anak.

\section{A. Pendahuluan}

Anak merupakan bagian penting sebagai generasi penerus dari suatu bangsa, dengan adanya regenerasi maka perlunya pendidikan dan pertumbuhan yang baik bagi seorang anak untuk melanjutkan pemerintahan yang masa datang, oleh karena itu melindungi hak-hak anak dari segenap tindakan-tindakan buruk yang dapat merugikan serta menyakiti fisik maupun psikis dari seorang anak.

Sebagaimana kita tahu bahwa anak yang masih di bawah umur, masih rentan terhadap pengaruh-pengaruh yang datang dari luar yang mana dapat berdampak negatif bagi dirinya bahkan mungkin bagi orang lain, tetapi karena jiwanya yang masih labil sehingga belum bisa menelaah apakah hal yang ia lakukan adalah baik atau buruk. Oleh karena itu seorang anak seharusnya mendapatkan bimbingan agar tidak melakukan sesuatu yang memberikan dampak negatif bagi dirinya dan orang lain, serta perlindungan terhadap hak-haknya agar tidak tertindas dari orang-orang yang mengambil keuntungan dan melepas tanggung jawabnya.

Anak-anak kian menjadi sosok yang terancam oleh orang dewasa, teman sebaya, dan kejahatan lain. Mereka ada yang diperdagangkan, diperkosa, disiksa, dan diperlakukan secara tidak adil, untuk itu anak-anak butuh perlindungan agar tidak mendapat perlakuan yang tidak senonoh. 
Menelaah mengenai kekerasan menurut Sanford Kadish mendefinisikan kekerasan dengan pengertian sebagai berikut "Kekerasan atau violence itu menunjuk pada tingkah laku yang bertentangan dengan undang-undang serta memiliki akibat-akibat baik berupa kerusakan fisik maupun kerusakan harta benda atau kematian seseorang. ${ }^{1}$

Pemerintah dalam hal ini berkewajiban memberikan perlindungan terhadap anak, dengan tidak mengenyampingkan hak orang tua terhadap seorang anak, yang mana pada anak di bawah umur, orang tua berkewajiban untuk melindung dan mendidik anak mereka serta bertanggung jawab atas keselamatannya. Perkembangan jaman, dan kebutuhan akan perlindungan anak yang semakin besar mendesak kita untuk memikirkan secara lebih, akan hak-hak anak karena di bahu merekalah, masa depan dunia tersandang.

Pemenuhan hak-hak anak, termasuk hak-hak atas perlindungan, tergantung pada suatu gerakan global di mana setiap orang tak hanya memahami dan menghormati kewajibannya terhadap anak-anak, namun juga bertindak atas nama anak-anak tersebut. Parlemen dan para anggotanya dapat, dan seyogyanya berada di barisan terdepan dalam memperjuangkan perlindungan anak. Mereka bisa membuat legislasi, mengawasi kegiatan pemerintah, mengalokasikan sumber-sumber daya finansial dan, sebagai pemimpin di dalam negara/bangsa dan masyarakat, mereka dapat membangkitkan kesadaran tentang isu-isu tersebut serta memberikan advokasi.

Pemerintah menganggap perlunya dibentuk suatu lembaga yang konsen terhadap perlindungan anak yang mana berfungsi untuk menjamin hak-hak anak yang mengalami tindasan dari berbagai pihak, maka presiden membentuk suatu lembaga dengan nama Komisi Perlindungan Anak Indonesia yang disingkat KPAI, yang kedudukannya setara dengan komisikomisi lain seperti KPK dan KPU, seharusnyalah lembaga yang dibentuk berdasarkan amanat Keppres Nomor 77 Tahun 2003 tentang Komisi Perlindungan Anak dan Pasal 74 UU No. 23 Tahun 2002 tentang Perlindungan Anak itu menyelesaikan konflik-konflik terhadap anak.

Komisi Perlindungan Anak Indonesia (KPAI) dibentuk berdasarkan UU 23 tahun 2002 tentang Perlindungan Anak. Pada Pasal 74 undangundang tersebut mengamanatkan pembentukan komisi tersebut. Megawati Soekarno Putri, Presiden saat itu lalu mengeluarkan Keppres Nomor 77 Tahun 2003 tentang Komisi Perlindungan Anak Indonesia. Sedangkan KPAI sendiri baru terbentuk tahun 2004.

Komisi Perlindungan Anak Indonesia adalah lembaga negara independen yang bertugas berdasarkan Undang-Undang No 23 tahun 2002

\footnotetext{
${ }^{1}$ Romli Atmasasmita, Teori dan Kapita Selekta Kriminologi, (Bandung: Erasco, 1992), hlm. 55.
} 
tentang Perlindungan Anak. Dalam Pasal 74 Undang-Undang tersebut disebutkan mereka bertugas meningkatkan efektivitas penyelenggaraan perlindungan anak.

Sebagai contoh kasusnya adalah permasalahan yang sedang dialami Arumi Bachsin melarikan diri dari orang tuanya yang diduga telah melakukan eksploitasi serta kekerasan terhadap dirinya, selain itu juga menjual anak di bawah umur, yaitu Arumi dengan tujuan seksual kepada seorang pengusaha yang dipersilahkan sekamar dengan Arumi.

Kemudian contoh kasus lainnya adalah kekerasan yang dilakukan oleh Muhammad Suryadi terhadap anak kandungnya sendiri "Almira Salfa Adinda" yang berusia 18 bulan, sehingga mengakibatkan anak balita tersebut meninggal dunia dengan luka di sekujur tubuhnya.

Banyaknya kasus-kasus kekerasan yang dialami anak, untuk itu perlunya suatu lembaga yang konsen terhadap perlindungan anak seperti Komisi Perlindungan Anak Indonesia, dalam hal ini sejauhmanakah peranan KPAI dalam perlindungan anak terhadap kasus kekerasan terhadap anak sehubungan dengan kewenangan orang tua terhadap anaknya.

Berdasarkan uraian dalam latar belakang yang telah di ungkapkan di atas, maka yang menjadi pokok permasalahan dalam penulisan ini adalah: 1) Bagaimanakah Implementasi Komisi Perlindungan Anak Indonesia (KPAI) dalam penanganan kasus kekerasan terhadap?; dan 2) Apakah faktor penghambat Komisi Perlindungan Anak Indonesia terhadap perlindungan kasus kekerasan terhadap anak?

Pendekatan masalah dengan digunakan adalah pendekatan yuridis normatif (legal research) dan pendekatan yuridis empiris. Pendekatan yuridis normatif adalah pendekatan yang menelaah hukum sebagai kaidah yang dianggap sesuai dengan penelitian yuridis normatif atau penelitian hukum tertulis. Pendekatan yuridis normatif dilakukan dengan cara melihat, menelaah hukum serta hal yang bersifat teoretis yang menyangkut asas-asas hukum, sejarah hukum, perbandingan hukum, taraf sinkronisasi yang berkenaan dengan masalah yang akan dibahas di dalam penelitian ini.

\section{B. Pembahasan}

\section{Peranan Komisi Perlindungan Anak Indonesia (KPAI) dalam Penanganan Kasus Kekerasan terhadap Anak oleh Orang Tua}

Anak merupakan generasi penerus bangsa yang harus dilindungi dan diberikan kehidupan yang layak, hal tersebut merupakan salah satu kewajiban orang tua, pemerintah dan masyarakat demi kelangsungan hidup anak sehingga dapat tumbuh dan berkembang dengan baik. Adapun pengertian anak menurut Pasal 1. Undang-Undang Nomor 23 tahun 2002 adalah seseorang yang belum berusia 18 tahun termasuk anak yang masih dalam kandungan. 
Demi terpenuhinya hak anak maka pemerintah mendirikan suatu lembaga yang konsen terhadap perlindungan anak, yaitu Komisi Perlindungan Anak Indonesia (KPAI). Lembaga ini merupakan satu-satunya lembaga yang diberi mandat oleh Undang-Undang untuk meningkatkan efektifitas penyelenggaraan perlindungan anak. Adapun kewajiban dan tanggung jawab negara dan pemerintah dalam perlindungan anak, yaitu: ${ }^{2}$

a. menjamin hak asasi setiap anak tanpa membedakan suku, agama, ras, golongan, jenis kelamin, etnik, budaya dan bahasa, status hukum anak, urutan kelahiran anak, dan kondisi fisik dan/atau mental;

b. memberikan dukungan sarana dan prasarana dalam penyelenggaraan perlindungan anak;

c. menjamin perlindungan, pemeliharaan, dan kesejahteraan anak dengan memperhatikan hak dan kewajiban orang tua, wali, atau orang lain yang secara hukum bertanggung jawab terhadap anak;

d. mengawasi penyelenggaraan perlindungan anak; dan

e. menjamin anak untuk menggunakan haknya dalam menyampaikan pendapat sesuai dengan usia dan tingkat kecerdasan anak.

Landasan hukum yang menjadi pijakan berdirinya KPAI adalah Keputusan Presiden RI. No. 77 Tahun 2003 tentang Komisi Perlindungan Anak Indonesia sebagai pelaksanaan atas mandat pada Pasal 74, 75, 76 Undang-Undang No. 23 Tahun 2002 tentang Perlindungan Anak.

Peranan Komisi Perlindungan Anak secara normatif sesuai dengan Pasal 76 Undang-Undang No. 23 Tahun 2002, memiliki tugas dan fungsi sebagai berikut:

a. melakukan sosialisasi segala ketentuan peraturan perundangan terkait perlindungan anak;

b. mengumpulkan data dan informasi;

c. menerima pengaduan masyarakat;

d. melakukan penelaahan, pemantauan dan evaluasi penyelenggaraan perlindungan anak; dan

e. memberikan laporan, saran, masukan, dan pertimbangan kepada Presiden dalam rangka perlindungan anak.

Komisi Perlindungan Anak secara ideal berperan memantau, mengawasi dan memberi dorongan agar penyelenggara perlindungan anak semakin efektif. Ini dituangkan secara eksplisit di dalam Undang-Undang (UU) Nomor 23 tahun 2002 tentang Perlindungan Anak. Perlunya perhatian pada aspek kemanusiaan, cara-cara penanganan itu bersifat demokratis, bahkan banyak kalangan terutama para akademisi menyatakan langkah yang tepat haruslah profesional.

\footnotetext{
${ }^{2}$ Hadi Supeno, Memehami Konveksi Hak-Hak Anak dan Undang-Undang Perlindungan
} Anak, (Jakarta: Zalco Pratama, 2010), hlm. 33 
Berdasarkan penelitian yang dilakukan di Komisi Perlindungan Anak Indonesia, menurut Sander Zulkarnaen mengatakan mereka bertugas meningkatkan efektivitas penyelenggaraan perlindungan anak. Ini memang terkesan grey area. Lalu menyosialisasikan seluruh aturan Perundangundangan terkait perlindungan anak, mengumpulkan data dan informasi, menerima pengaduan masyarakat, melakukan penelaahan dan melakukan pemantauan, evaluasi dan pengawasan. Juga menyampaikan saran, masukan dan pertimbangan kepada Presiden. Selain itu kami juga mengajukan judicial review terhadap UU No 3 Tahun 1997 tentang Pengadilan Anak. Kita juga mengadvokasi pemerintah tentang Sistem Perlindungan Anak. Ini karena perlindungan anak dan pemenuhan hak-haknya di negeri ini, masih belum sistemik, masih parsial dan segmentaris.

Komisi Perlindungan Anak Indonesia adalah lembaga independen yang kedudukannya setingkat dengan komisi negara yang dibentuk berdasarkan amanat Keppres No. 77 Tahun 2003. Lembaga ini bersifat independen, tidak boleh dipengaruhi oleh siapapun dan di mana serta kepentingan apapun, kecuali satu yakni demi kepentingan terbaik bagi anak.

Sebagai sebuah lembaga negara, fokus perhatian KPAI lebih kepada penguatan kelembagaan seperti merumuskan tata tertib, merumuskan rencana strategis, menyusun program jangka pendek dan jangka panjang serta penataan kegiatan tahun berjalan, melengkapi sarana prasarana, melengkapi struktur organisasi dengan membentuk kelompok kerja dan tim ahli, tenaga sekretariat, pedoman-pedoman internal dan mekanisme kerja serta pedoman pembentukan KPAID. ${ }^{3}$

Menurut Turaihan Aldi juga menyampaikan bahwa KPAI tidak aktif menangani advokasi terhadap kasus- kasus mengenai anak, tetapi seharusnya lebih banyak melakukan advokasi kebijakan, seperti sosialisasi pembuatan Perda, mendorong pemenuhan hak anak yang sering lepas dari perhatian.

Pada kenyataannya KPAI lebih banyak menangani kasus-kasus mengenai kekerasan terhadap anak. Kemudian dilakukan penelitian di kantor KPAI, beberapa peranan Komisi Perlindungan Anak secara factual menurut Sander Diki Zulkarnaen menyatakan bahwa Banyak sekali Kementerian yang menangani anak, seperti Kemensos, Kemenakertrans, Kemendiknas, Kemenkes dan Pemberdayaan Perempuan, tapi tidak juga terkoordinasi dengan baik, karena belum sistemik. Komisi Perlindungan Anak mempertanyakan UU Sistem Perlindungan Anak. Kemudian juga aktif menegur kebijakan pemda yang tidak sesuai dengan kepentingan pemenuhan hak anak. Seperti Pemkab Pandeglang Banten yang mempersulit akte kelahiran bagi anak-anak di pedalaman, anak-anak suku Badui. Selain itu turun tangan untuk ikut mendudukkan secara proporsional kasus

\footnotetext{
${ }^{3}$ Hadi Supeno, Potret Anak Indonesia, (Jakarta: Graha Putra, 2010), hlm. 45.
} 
pembunuhan seorang nenek di Kediri oleh anak berusia 9 tahun dan 11 tahun. Hasil penelitian menunjukkan kedua anak ini membunuh karena disuruh ibunya. Setelah kami turun tangan, maka anak dibebaskan dan ibunya dihukum berat. Jadi anak-anak ini adalah korban perintah jahat ibunya. Juga terhadap kasus Syeh Puji, turun tangan. melaporkan kemacetan kasus ini ke Jaksa Agung, sehingga kasus Syeh Puji akhirnya bisa diteruskan, disamping itu tugas Komisi Perlindungan Anak Indonesia mendorong polisi dalam menyelesaikan kasus kekerasan terhadap anak.

Berdasarkan wawancara kepada akademisi Fakultas Hukum Universitas Lampung, Sunarto menyatakan bahwa dalam penanganan kasus seharusnya Komisi Perlindungan Anak bertindak sebagai mediator, yaitu sebagai penghubung antar lembaga seperti kepolisian, LPSK, dan pihak terkait, selain itu juga mencari tau serta melakukan investigasi mengenai kasus kekerasan yang dialami seorang anak.

Upaya perlindungan terhadap anak perlu dilaksanakan sedini mungkin, bertitik tolak dari konsepsi perlindungan anak yang bertujuan untuk menjamin terpenuhinya hak anak agar tetap hidup, tumbuh, berkembang, dan berpartisipasi secara optimal sesuai dengan harkat dan martabat manusia, serta mendapat perlindungan dari kekerasan dan diskriminasi demi terwujudnya anak Indonesia yang berkualitas, berakhlak mulia dan sejahtera. ${ }^{4}$

Menurut penulis upaya perlindungan anak amatlah penting, demi mewujudkan kesejahteraan anak, namun Komisi Perlindungan Anak Indonesia tidak memiliki kapasitas yang cukup dalam menangani kasus kekerasan terhadap anak, yang mana kapasitas Komisi Perlindungan Anak Indonesia masih sangat terbatas dengan peraturan perundang-undangan yang dapat bertindak sebatas mediator dalam melakukan penanganan kasus kekerasan terhadap anak. Seharusnya lebih banyak melakukan advokasi kebijakan, melakukan sosialisasi terhadap peraturan perundang-undangan sesuai dengan apa yang telah ditentukan dalam peraturan perundangundangan yang berlaku sehingga masyarakat dapat mengerti hak dan kewajiban anak dan masyarakat berdasarkan peraturan perundang-undangan.

Banyaknya kekerasan yang dilakukan orang tua terhadap anaknya merupakan salah satu faktor yang dapat merusak mental anak yang seharusnya dapat tumbuh kembang dengan baik dan mendapatkan haknya sebagai seorang anak sebagai harkat dan martabatnya sejak lahir. Untuk itu menurut penulis pentingnya sosialisasi mengenai hak anak serta hak dan kewajiban orang tua dan masyarakat dalam penyelenggaraan perlindungan

${ }^{4}$ Barda Nawawi, Beberapa Aspek Kebijakan Penegakkan dan Pengembangan Hukum Pidana, (Bandung: Citra Aditya Bakti, 2006), hlm. 4. 
anak sehingga masyarakat dapat mengerti dan memahami situasi serta memberikan pendidikan yang baik bagi anak tanpa menggunakan kekerasan.

Sebagai contoh kasus kekerasan terhadap anak seperti yang dialami oleh Arumi Bachsin yang melakukan pengaduan kepada KPAI tentang kekerasan yang dilakukan orangtuanya. Setelah melakukan wawancara di KPAI, menurut Sander Diki Zulkarnaen bahwa kasus Arumi Bachsin adalah kasus anak yang tereksploitasi ekonomi dan seksual, menjadi tulang punggung keluarga dan tidak mendapat kebahagiaan dari orang tua, menyangkut eksploitasi seksual, yaitu orang tua menjodohkan Arumi pada orang yang tidak disukai yang mana arumi masih berumur 17 tahun. Seperti yang disebutkan dalam artikel bahwa Arumi telah melaporkan ibundanya Maria Lilian Pesch ke Polda Metro Jaya pada 25 Oktober 2010, dengan tuduhan melakukan kekerasan psikis sebagaimana diatur dalam pasal 99 Undang-Undang No. 23 tahun 2002 tentang Perlindungan Anak, serta eksploitasi anak yang tertuang dalam pasal 45 Undang-Undang Nomor 23 tahun 2004 tentang KDRT. ${ }^{5}$

Menurut Sander Diki Zulkarnaen, dalam penuntutan orang tua, perlu dilihat kewenangan KPAI pada Pasal 26 Undang-Undang Nomor 23 tahun 2002 tentang Perlindungan Anak, apabila keluarganya yang bermasalah maka dibatasi dengan kewenangan keluarga, karena KPAI memiliki amanat Undang-Undang yang diberikan Undang-Undang. Pada Kasus ini meskipun merupakan kasus eksploitasi anak, tetapi yang melapor adalah Arumi telah mencabut laporannya kepada kepolisian, kemudian ada gelar perkara yang dilakukan di kediaman Arumi Bachsin dan keluarga, dengan melakukan kerjasama antara kepolisian dan perlindungan saksi dan korban, juga dilakukan rehabilitasi secara psikis pada anak yang mengalami trauma.

Setelah melakukan wawancara di Lembaga Advokasi Anak, menurut Turaihan Aldi kapasitas KPAI dibuat oleh pemerintah untuk mendorong kebijakan Perundang-undangan, Peraturan Menteri, dan Peraturan Daerah. Namun, KPAI harus tetap memberikan perlindungan kepada anak ketika meminta perlindungan, dalam kasus ini termasuk menyembunyikan Arumi Bachsin yang sejak lahir telah melekat harkat dan martabat anak, jika tidak ditangani dikhawatirkan akan menurun lagi ke anaknya.

Definisi perlindungan anak adalah segala kegiatan untuk menjamin dan melindungi anak dan hak-haknya agar dapat hidup, tumbuh, berkembang, dan berpartisipasi, secara optimal sesuai dengan harkat dan martabat kemanusiaan, serta mendapat perlindungan dari kekerasan dan diskriminasi. ${ }^{6}$

\footnotetext{
${ }^{5} \mathrm{http}: / /$ celebrity.okezone.com/read/2011/03/23/33/438163

${ }^{6}$ Hadi Supeno. Dari wasior, Mentawai, Sampai Merapi. (Jakarta: Graha Putra, 2010), hlm. 28.
} 
Secara ideal mengenai kasus kekerasan terhadap anak, menurut Sunarto seharusnya lembaga seperti Komisi Perlindungan Anak Indonesia lebih profesional sesuai prosedur dalam bertindak, menyembunyikan anak dari orang tua hal tersebut seperti penyekapan, meskipun itu merupakan kehendak dari anak tersebut, yang mana dalam setiap kasus harus dilihat dulu permasalahannya, misalnya orang tua memukul anak, harus dilihat dulu anaknya mungkin saja anak itu sangat bandel atau menggunakan narkoba, atau mungkin melakukan tindakan yang di luar batasan. Begitu pula dengan kasus Arumi Bachsin, banyak masalah yang harus dilihat secara luas, misalnya seringnya Arumi Bachsin lari, bahwa ia adalah seorang artis, mengenal banyak orang, mengenal duit, dan juga mengenal lelaki. Nah itu semua seharusnya juga menjadi pertimbangan dalam melakukan tindakan.

Contoh kasus di atas penulis beranggapan bahwa memang seharusnya Komisi Perlindungan Anak Indonesia menjadi mediator yang baik antara orang tua dan anak sesuai dengan prosedurnya, meskipun pihak terkait tidak menginginkan demikian, namun tetap harus melihat permasalahan dari beberapa aspek dan juga mempertimbangkan kedua belah pihak, yang mana ada beberapa kemungkinan yang dapat terjadi pada permasalahan tersebut.

Adapun mekanisme kerja Komisi Perlindungan Anak Indonesia yang tercantum pada pasal 15 Keppres No 77 Tahun 2003 tentang Komisi Perlindungan Anak Indonesia adalah

a. pelaksanaan tugas Komisi Perlindungan Anak Indonesia dilakukan dengan mengutamakan musyawarah untuk mufakat; dan

b. laporan, saran, masukan, dan pertimbangan kepada presiden disampaikan atas dasar kesepakatan anggota Komisi Perlindungan Anak Indonesia.

\section{Faktor Penghambat Komisi Perlindungan Anak Indonesia terhadap Perlindungan Kasus Kekerasan terhadap Anak}

Setiap aktivitas suatu organisasi atau lembaga memiliki beberapa aspek yang dapat menghambat efektivitas kinerja suatu lembaga, begitu pula dengan lembaga yang konsen terhadap perlindungan anak seperti LSM serta lembaga yang dibuat oleh Presiden RI yaitu Komisi Perlindungan Anak Indonesia, seperti dalam Pasal 74 Undang-Undang No. 23 Tahun 2002 tentang Perlindungan Anak menerangkan bahwa dalam rangka meningkatkan efektivitas penyelenggaraan perlindungan anak, dengan ini dibentuk Komisi Perlindungan Anak Indonesia yang bersifat independen.

Beberapa Faktor penghambat Komisi Perlindungan Anak dalam menangani kasus kekerasan terhadap anak dapat dilihat dari beberapa aspek, seperti berikut: 


\section{a. Kaidah Hukum}

KPAI tidak memiliki mandat untuk legal standing atau eksekusi seperti KPK, tidak memiliki legitimasi untuk langsung bergerak dan mengambil tindakan terhadap anak yang mengalami kekerasan. KPAI harus bekerja sama dengan pihak kepolisian dan kejaksaan.

Menurut Hadi Supeno dalam Warta KPAI edisi IV tahun 2010 menyatakan bahwa pada kurun waktu yang sangat pendek, sejumlah peran telah dilakukan dengan segala plus minusnya. Namun belum memuaskan masyarakat, karena persoalan perlindungan anak memang sangat kompleks dan eksistensinya diamanatkan untuk "meningkatkan efektifitas penyelenggaraan perlindungan anak" sering disalah mengerti oleh masyarakat dengan harapan lembaga ini menjadi lembaga super body atau sapu jagad sebagaimana Komisi Pemberantasan Korupsi (KPK) yang bisa menangkap tangan orang yang sedang melakukan pelanggaran hukum. Sementara KPAI hanya berada pada ranah meng-efort, mendorong, dan merekomendasikan, sementara eksekusi tetaplah ada pada para penyelenggara perlindungan anak.

Kemudian juga menurut Turaihan Aldi bahwa selama ini dalam praktiknya KPAI belum berperan banyak, karena KPAI seharusnya lebih berperan pada kebijakan-kebijakan perlindungan anak, hal itu disebabkan KPAI lebih pada tugas-tugas pemerintahan yang membuat mereka lebih fleksibel bergerak.

\section{b. Penegak Hukum}

Banyaknya aparat penegak hukum yang masih menjadi pelaku tindak kekerasan terhadap anak memperparah kondisi di mana masyarakat kita masih banyak melakukan tindak kekerasan terhadap anak dalam berbagai bentuk baik kekerasan fisik, psikis, maupun seksual. Aparat penegak hukum hampir selalu melakukan kriminalisasi anak, terhadap anak-anak yang berkonflik dengan hukum, tanpa berusaha melakukan diversi agar penghukuman cukup dilakukan dengan tindakan kasus pemidanaan anak yang dituduh berjudi, penembakan seorang anak oleh oknum polisi, Penyiksaan seorang anak di depan orang tuanya, dan berbagai kasus lainnya sebagaimana laporan dari berbagai pihak kepada KPAI. ${ }^{7}$

Berkaitan dengan anak-anak yang menjadi korban kekerasan, perspektif perlindungan anak para aparat penegak hukum masih sangat memprihatinkan dan belum menunjukkan keberpihakannya terhadap anak. Hal ini ditunjukkan dengan lambatnya penanganan kasus-kasus kekerasan terhadap anak, rendahnya vonis pengadilan terhadap para pelaku kekerasan

\footnotetext{
${ }^{7}$ www.wawasandigital.com diakses pada tanggal 5 Oktober 2011.
} 
terhadap anak karena banyak aparat penegak hukum yang tidak menggunakan Undang-Undang Nomor 23 Tahun 2002 tentang Perlindungan Anak dalam proses peradilan di mana anak menjadi korban.

\section{c. Fasilitas}

Salah satu unsur yang menjadi faktor penghambat kinerja Komisi Perlindungan anak adalah fasilitas, sarana dan prasarana yang tidak mencukupi. Menurut Sander Diki Zulkarnaen di KPAI bahwa salah satu faktor penghambat kinerja KPAI minimnya dukungan infrastruktur yang peduli terhadap anak karena KPAI bukan seperti KPK yang tidak memiliki banyak kepentingan dalam Pemilu sebagaimana anak belum cukup umur untuk ikut serta dalam pemilu, sehingga pemerintah masih setengah hati, dan anak tidak strategis kedudukannya.

Komisi Perlindungan Anak Indonesia (KPAI) yang jelas-jelas memperoleh mandat dari Undang-Undang No. 23 Tahun 2002 tentang Perlindungan Anak sekedar lips service saja. Anggaran yang disediakan untuk lembaga yang mestinya menyosialisasikan seluruh ketentuan peraturan perundang-undangan ini terkecil dari semua Komisi Negara, berbeda dengan Komnas Perlindungan Anak yang menempati gedung milik Kemensos, setiap tahun memperoleh subsidi, termasuk kegiatan kongres anak yang membiayai adalah Kementerian Sosial. ${ }^{8}$

Menurut Sunarto beberapa kendala dan hambatan yang mempengaruhi kinerja Komisi Perlindungan Anak Indonesia kemungkinan disebabkan minimnya fasilitas, sarana dan prasarana yang belum cukup memadai dari pemerintah, dana yang kurang untuk pembiayaan bantuan dan perlindungan hukum bagi anak korban tindak kekerasan serta adanya anggapan dari sebagian masyarakat bahwa perlakuan kasar dan keras kepada anak-anak sebagai masalah intern keluarga dan dianggap sebagai bagian dari proses pendidikan sehingga tidak perlu dicampuri oleh pihak lain dan diekspose keruang publik.

\section{d. Masyarakat}

Sesuai dengan Pasal 25 Undang-Undang No 23 Tahun 2002 tentang Perlindungan Anak bahwa kewajiban dan tanggung jawab masyarakat terhadap perlindungan anak dilaksanakan melalui kegiatan peran masyarakat dalam penyelenggaraan perlindungan anak. Pada Pasal tersebut di atas diterangkan bahwa dalam perlindungan anak masyarakat memunyai

\footnotetext{
${ }^{8}$ Hadi Supeno, Dari wasior, Mentawai, Sampai Merapi, (Jakarta: Graha Putra, 2010), hlm. 88 .
} 
kewajiban untuk ikut serta meningkatkan penyelenggaraan serta melindungi hak anak.

Berdasarkan penelitian di Lembaga Advokasi Anak, Turaihan Aldi berpendapat mengenai kendala-kendala dalam menangani kasus kekerasan terhadap anak yang dilakukan oleh orang tua, yaitu:

1) minimnya pemahaman mengenai hak anak, sehingga mereka berfikir bahwa kekerasan terhadap anak adalah hak orang tua; dan

2) kecenderungan masyarakat menganggap bahwa anak merupakan hak milik orang tua, padahal menurut Undang-Undang masyarakat memiliki hak untuk melindungi anak.

Pemahaman masyarakat yang masih beranggapan bahwa beliau adalah penguasa atas anak mereka, merupakan salah satu penghambat dalam penanganan kasus kekerasan terhadap anak, hal tersebut berkaitan dengan kesadaran mereka terhadap hak dan kewajiban anak serta hak dan kewajiban orang tua yang berhubungan dengan sosialisasi penyelenggaraan perlindungan anak.

\section{e. Kebudayaan}

Kebudayaan merupakan adat atau kebiasaan yang tumbuh dalam masyarakat dan terus menerus berkembang serta dianut suatu kelompok masyarakat. Berdasarkan wawancara dengan akademisi Universitas Lampung, Sunarto berpendapat bahwa secara normatif Komisi Perlindungan Anak telah menjalankan peranannya, tetapi pada faktualnya belum terlihat secara aksi nyata, banyaknya tindakan kekerasan yang ada dalam lingkungan keluarga sulit dideteksi, sulit dijangkau, kalaupun ada yang terungkap karena diberitakan di media massa, dan sangat meresahkan masyarakat seperti inces. Menurutnya sulitnya dideteksi tindakan kekerasan terhadap anak disebabkan karena tidak adanya laporan, ketidaktahuan publik tentang hak dan kewajiban anak dan orang tua, aib keluarga, dan juga keterbatasan petugas.

Anak sebagai sasaran kekerasan rupanya belum berhenti dalam masyarakat kita. Ia masih menjadi objek kekerasan di rumah, di sekolah, maupun di masyarakat dalam berbagai bentuk dari kekerasan fisik, kekerasan psikis, kekerasan seksual, serta kekerasan sosial. Jumlah kekerasan sosial juga dari hari ke hari terus bermunculan. Tren pengaduan di KPAI juga menunjukkan peningkatan yang signifikan.

Pada Warta KPAI edisi I tahun 2010 Hadi supeno menggambarkan faktor-faktor yang menyebabkan banyaknya terjadi kekerasan terhadap anak, sebagai berikut:

1) karena anak dalam posisi lemah dan rentan, Ia tidak bisa melawan seperti halnya orang dewasa. ia mudah ditaklukkan, dibujuk rayu, ditipu, dengan 
janji-janji atau iming-iming materi untuk menjadi sasaran kekerasan, juga eksploitasi;

2) ada tradisi negatif yang berkembang dalam masyarakat kita, bahwa kekerasan adalah hal yang lumrah. Banyaknya adat di tanah air yang bermuatan kekerasan;

3) kesalahan cara pandang dalam praktik pendidikan baik di rumah maupun di sekolah. Banyak pendidikan beranggapan, menghukum fisik adalah metode terbaik dalam pendidikan, agar anak patuh dan disiplin; dan

4) sasaran ketidakberdayaan orang tua yang sedang mengalami tekanan, baik tekanan ekonomi maupun tekanan psikis. Motif ini biasanya paling berbahaya karena ekspresi orang tua bisa juga terkendali dan di luar dugaan. Ia bukan hanya akan mengancam, tetapi juga menyakiti anak bahkan membunuhnya, tanpa alasan yang jelas, karena semata-mata mencari rasa lega atau kepuasan dalam dirinya sebagai kompensasi atas tekanan batin yang dirasakan. Sementara untuk tekanan ekonomi, larinya pada tindakan eksploitasi bermotif ekonom.

Faktor keterbatasan kemampuan dikarenakan anak berada pada proses pertumbuhan, proses belajar, dan proses sosialisasi dari akibat usia yang belum dewasa, disebabkan kemampuan daya nalar (akal) dan kondisi fisik dalam pertumbuhan atau mental spiritual yang berada di bawah kelompok usia orang dewasa. ${ }^{9}$

Jika berbicara tentang kekerasan selalu ada subjek yang melakukan kekerasan dan ada objek yang menerima kekerasan. Kekerasan itu sendiri adalah akibat dari sebuah hubungan/relasi, sehingga kekerasan dapat didefinisikan secara luas dan netral, yaitu sebuah aktivitas yang sadar atau tidak sadar, yang memasukkan sebuah objek dalam unsur subjek. ${ }^{10}$

Definisi anak merupakan amanah dan anugrah dari Tuhan Yang Maha Esa yang dalam dirinya melekat harkat dan martabat sebagai manusia seutuhnya. Setiap anak memunyai harkat dan martabat yang patut dijunjung tinggi dan setiap anak terlahir harus mendapatkan hak-haknya tanpa anak tersebut meminta. ${ }^{11}$

Sedangkan perlindungan anak adalah istilah yang digunakan secara luas, namun kadang-kadang tidak dipahami secara jelas. Di bawah Konvensi Hak Anak (KHA) Perserikatan Bangsa-Bangsa (PBB), anak memiliki hak khusus atas perlindungan dari segala bentuk perlakuan salah dan eksploitatif. Perlindungan anak bertujuan untuk menjamin adanya lingkungan protektif

\footnotetext{
${ }^{9}$ Maulana Hasan Wadong, Pengantar Advokasi dan Hukum perlindungan Anak, (Jakarta: Grasindo, 2000), hlm. 5.

${ }^{10}$ Lucien Van Liere, Memutus Rantai Kekerasan, (Jakarta: Gunung Mulia, 2010), hlm. 47.

${ }^{11}$ Rika Saraswati, Hukum Perlindungan Anak di Indonesia, (Bandung: Citra Aditya Bakti, 2009), hlm. 1.
} 
bagi setiap anak yang melindungi mereka dari perlakuan salah eksploitasi, kekerasan, penelantaran dan diskriminasi. ${ }^{12}$

Saat melindungi anak secara optimal diperlukan lingkungan yang protektif, di lingkungan mana setiap orang menjunjung tinggi tanggung jawab untuk menjamin bahwa anak benar-benar dilindungi dari perlakuan salah, eksploitasi, kekerasan dan diskriminasi.

Menurut penulis upaya yang harus dilakukan berupa sosialisasi oleh para instansi-instansi yang konsen dalam perlindungan anak secara kontinu demi meminimalisir kekerasan yang dialami anak. Seperti yang tercantum pada pasal 28 B ayat (2) UUD 1945 menjelaskan secara eksplisit bahwa "Setiap anak berhak atas kelangsungan hidup, tumbuh dan berkembang serta berhak atas perlindungan dari kekerasan diskriminasi”. Mandat Konstitusi ini sangat jelas dan karenanya harus diamankan oleh siapapun, bagi lembaga atau badan yang memang dibentuk untuk melindungi anak.

\section{Penutup}

\section{Simpulan}

Peranan Komisi Perlindungan Anak Indonesia secara normatif melakukan sosialisasi segala ketentuan peraturan perundangan terkait perlindungan anak, mengumpulkan data dan informasi, menerima pengaduan masyarakat, melakukan penelaahan, pemantauan dan evaluasi penyelenggaraan perlindungan anak. Secara ideal berperan memantau, mengawasi dan memberi dorongan agar penyelenggara perlindungan anak semakin efektif, melakukan advokasi kebijakan, serta bertindak sebagai mediator dalam penanganan kasus kekerasan terhadap anak, berada pada ranah meng-efort, mendorong, dan merekomendasikan, sementara eksekusi tetaplah ada pada para penyelenggara perlindungan anak.

Faktor-faktor yang menjadi penghambat Komisi Perlindungan Anak Indonesia dalam menangani kasus kekerasan terhadap anak dari beberapa aspek:

1. Kaedah Hukum

a. Komisi Perlindungan Anak tidak memiliki mandat legal standing atau eksekusi,

b. KPAI lebih berperan dalam kebijakan- kebijakan dan advokasi perlindungan anak, bukan penanganan kekerasan terhadap anak.

2. Penegak Hukum

a. Banyaknya aparat penegak hukum yang masih menjadi pelaku tindak kekerasan terhadap anak

\footnotetext{
${ }^{12}$ Hadi Supeno, et. al, Dari wasior, Mentawai, Sampai Merapi, (Jakarta: Graha Putra, 2010), hlm. 22.
} 
b. Aparat penegak hukum masih memprihatinkan dalam bertindak dan belum menunjukkan keberpihakannya terhadap anak.

3. Fasilitas

a. minimnya dukungan infrastruktur yang perduli terhadap anak

b. Anggaran yang disediakan untuk lembaga yang mestinya mensosialisasikan seluruh ketentuan peraturan perundang-undangan ini terkecil dari semua Komisi Negara.

4. Masyarakat

Pemahaman mengenai hak anak, sehingga mereka berfikir bahwa kekerasan terhadap anak adalah hak orang tua.

5. Kebudayaan

a. Karena anak dalam posisi lemah dan rentan. Kesalahan cara pandang dalam praktik pendidikan baik di rumah maupun di sekolah.

b. Sasaran ketidakberdayaan orang tua yang sedang mengalami tekanan, baik tekanan ekonomi maupun tekanan psikis.

Hal-hal dari beberapa aspek tersebut diatas yang menjadi faktor penghambat Komisi Perlindungan Anak dalam menangani kasus kekerasan terhadap anak.

\section{Saran}

a. Upaya Penyelenggaraan perlindungan anak telah dilakukan oleh pemerintah dengan mendirikan Komisi Perlindungan Anak Indonesia, maka sudah seharusnyalah melaksanakan kinerjanya benar-benar secara efektif dan professional sehingga perlindungan anak dapat benar-benar ditegakkan.

b. Pemerintah memberikan infrastruktur yang baik, juga fasilitas, sarana dan prasarana yang memadai, serta dana untuk pembiayaan bantuan dan perlindungan hukum bagi anak korban tindak kekerasan

c. Diharapkan bagi masyarakat dapat mengerti dan memahami hak anak dan juga hak dan kewajibannya sebagai masyarakat sehingga penyelenggaraan perlindungan anak dapat terlaksana semaksimal mungkin.

\section{Daftar Pustaka}

\section{A. Buku}

Atmasasmita, Romli, 1992, Teori dan Kapita Selekta Kriminologi, Bandung: Erasco.

Nawawi A, Barda, 2006, Beberapa Aspek Kebijakan Penegakkan dan Pengembangan Hukum Pidana, Bandung: Citra Aditya Bakti. 
Saraswati, Rika, 2009, Hukum Perlindungan Anak di Indonesia, Bandung: Citra Aditya Bakti.

Supeno, Hadi, 2010, Memehami Konveksi Hak-Hak Anak dan UndangUndang Perlindungan Anak. Jakarta: Zalco Pratama.

Supeno, Hadi, et. al., 2010, Potret Anak Indonesia, Jakarta: Graha Putra. Graha Putra.

Van Liere, Lucien, 2010, Memutus Rantai Kekerasan, Jakarta: Gunung Mulia.

Wadong, Maulana Hasan, 2000, Pengantar Advokasi dan Hukum perlindungan Anak, Jakarta: Grasindo.

\section{B. Undang-undang}

Undang-Undang Dasar 1945

Undang-Undang Nomor 23 Tahun 2002 tentang Perlindungan Anak

Keputusan Presiden Nomor 77 Tahun 2003 tentang Komisi Perlindungan Anak

\section{Internet}

Warta KPAI Edisi I tahun 2010

Warta KPAI Edisi IV tahun 2010

http://celebrity.okezone.com/read/2011/03/23/33/438163

www.wawasandigital.com tertanggal 5/10/11 